INTERDISCIPLINARY RESEARCH PAPERS

This column publishes interdisciplinary research papers (relevant to law in context).

\title{
ECONOMICS OF COPYRIGHT: Challenges And Perspectives
}

\section{Abstract}

Aleksandar Stojkov, Goce Naumovski, \& Vasko Naumovski *

This article outlines the prominence of economic analysis of copyright, not only within the academic community, but also in the legal practice. The successful cooperation of law and economics in the field of copyright calls for advanced microeconomic analytical skills and a high level of legal understanding of intellectual property. The study highlights the central dilemma between access of copyright users and incentives to authors, by raising important issues under the umbrella of the microeconomics of copyright and macroeconomic consequences of piracy.

\section{Key words:}

Innovation, development, law and economics

DOI http://dx.doi.org/10.4314/mlr.v7i1.6

\section{Introduction}

The indispensability of analyzing intellectual property rights through the economic lenses is an outcome of the concept of intellectual property as a social phenomenon. In particular, both economics and intellectual property are closely affiliated with innovation, technology, and development.

Kamil Idris, the former Director General of the World Intellectual Property Organization (hereinafter: WIPO) underscored the economic perspective on the copyright in one of his addresses:

"[...] In the XXI century, intellectual property is no longer seen as an autonomous and separate area and has become a significant tool for policy-

* Aleksandar Stojkov (Ph.D), Goce Naumovski (Ph.D), Vasko Naumovski (Ph.D) Iustinianus Primus Faculty of Law, Ss. Cyril and Methodius University, Blvd. Goce Delcev 9b, 1000 Skopje, Republic of Macedonia. 
making with socio-economic, technological and cultural repercussions. This has led to increased demand for up-to-date and specific information on a range of intellectual property-related activities in order to facilitate planning by governments. Copyright and related rights in particular are closely linked to economic growth in several fields of activity concerned with the creation and production of literary and artistic works that are the focus of cultural activities.." (Idris, 2001).

The following section outlines the basic theoretical aspects of the interaction of law and economics, and the second section deals with the economics of copyright as one of the pillars of intellectual property. Piracy is highlighted in section 3, and the bidirectional causal link between copyright protection and economic development is briefly discussed in the last section.

\section{The Emergence of Economic Analysis of Law}

\subsection{Law and Economics: A Lasting Love Affair}

Until recently, the overlapping academic interests of law and economics mostly comprised of the following areas: antitrust law, regulated industries, tax and determination of monetary damages. However, since the early 1960s, the interaction between the two disciplines changed dramatically and expanded into the more traditional areas of the law, such as: property, contracts, torts, criminal law and procedure, and constitutional law. In order to address the new challenges, the economic science has penetrated into the nature of legal scholarship, the common understanding of legal rules and institutions and even the practice of law.

The economic approach to the most important development in legal scholarship of the XX century will therefore focus on several areas: increasing presence of economists in law schools; introduction of joint degree programs at many prominent universities; growing number of articles in law reviews and number of specialized journals with an economic content; development of new curricula such as introductory courses on economics and company law. Another indicator of the deepening collaboration between the two disciplines is the growing number of professional organizations in the United States, Europe, Canada, Latin America, and Australia. A typical example of the importance of the interdisciplinary approach of law and economics has also been the fact that several influential economists who contributed to the economic analysis of law have become Nobel laureates (Kenneth Arrow in 1972, Ronald Coase in 1991, and Gary Becker in 1992).

In practice, the tools of economic analysis are absorbing increasing attention of the legal profession. The greater content of economic analysis in the verdicts of judges and the regulatory impact assessment practices seem to be the most notable case. Within this context, economics has practically provided foundation for the deregulation movement in the 1970s and the renewed interest in the 
antitrust law in the United States during the 1970s and the 1980s. These tendencies are nowadays present in the European Union, as well.

In the last fifty years, several key issues of the economic theory have acquired greater interdependence with the legal science: the productive and allocative (Pareto) efficiency; costs (opportunity and transaction costs); incentive effects and risk aversion; free riding; the prisoners dilemma and Nash equilibrium; dominant strategy; asymmetric information; collective choice; open-access resource; median rule; market failure; monopoly power and price discrimination; cost-benefit analysis etc. (e.g., Towse, 2008; Conley and Yoo, 2009). A separate strand of the literature has examined the nexus between copyright laws and technological and economic development (e.g., Smith et al. 2009; Walter, 2010).

On the other hand, the influence of economics to law has been mainly manifested in areas and themes such as effective property and contract rights, litigation costs, liability and default rules, strict liability, independent judiciary, third-party enforcers, corruption, reliance damages, priority in bankruptcy, insider-trading, public firms and non-governmental organizations, customs, norms and internalized values, rational actors and on-monetary sanctions.

\subsection{Economic Analysis of Law: What It is All About?}

Economics provides a behavioral theory to predict the response of agents to changes in laws and a useful normative standard for evaluating law and policy. As Hsiung (2006) underscores, by behavioral theory, what is meant is that economists have, through their study of human (and non-human) behavior, come up with a set of principles that reflect, to a certain degree at least, the regularities of human (and non-human) behavior. This emerges from the fact that laws are instruments for achieving social goals. Therefore, lawmakers and judges must have a method of evaluating the impact of law on important social values. Efficiency or distribution of income and wealth are such values and therefore, it is always better to achieve any given policy at lower cost and to avoid leaving certain decisions to policy makers or voters. Analogous to the typical example of the rabbit population of Australia, economics found a vacancy in the intellectual ecology of the law and rapidly filled it.

The following basic economic concepts are often considered as the main pillars of the economic analysis of law:

a) Maximization. In economics, rational behavior is connected with maximization of satisfaction for consumer, profit for producer, votes for politicians, social welfare for charity, etc. (maximization under a feasibility constraint);

b) Equilibrium, usually defined as a pattern of interaction (occurring in markets, elections, clubs, games, teams, corporations or marriages) that 
persists unless disturbed by outside forces. Equilibrium can be characterized as stable, i.e. one that will not change unless outside forces intervene;

c) Efficiency. The main types of efficiency are: the productive efficiency when it is not possible to produce the same amount of output using a lower-cost combination of inputs, or it is not possible to produce more output using the same combination of inputs; and allocative or Pareto efficiency when if it is impossible to change it so as to make at least one person better off (in his own estimation) without making another person worse off (again in his own estimation);

d) Monopoly and market power, which are undesirable in terms of efficiency with the important exception of the natural monopoly (technological barrier of entry, economies of scale are a condition of production in which the greater the level of output, the lower the average production cost). The main corrective public policies of this phenomenon are: a) replacement of monopoly with competition (so called antitrust policies) and b) regulation of the monopolist's price in the case of natural monopolies.

e) Positive or negative externalities. Sometimes the benefits or costs of an exchange may spill over onto other parties than those explicitly engaged in the exchange, creating external benefits or costs. The example of the beekeeper that lives next to the apple orchard, providing pollination of the trees is a well-known illustration of positive externalities, while the situation of factory toxic materials destroying the lake biodiversity would be a good explanation for the negative externalities. In the second case, the private marginal cost (production cost of the factory) is less than the social marginal cost (private cost plus the additional marginal cost involuntary imposed on third parties). From the society's point of view, the profit maximizing output is inconsistent with the welfare maximization objective, because the firm behavior imposes detrimental effects on the welfare of other agents and incurs costs for environmental protection.

f) Private and public goods: commodities with closely related characteristics. First, the non-rival consumption, i.e. the tendency that the consumption of a public good by one person does not leave less for any other consumer and second, the non-excludability: the costs of excluding nonpaying beneficiaries, who consume the good, are so high that no private profit-maximizing firm is willing to supply the good.

g) Severe informational asymmetries: imbalance of information between parties to an exchange, which may generate unequal negotiating power in establishing contracts. 


\section{Economics of Copyright}

\subsection{The Intellectual Property}

A typical definition of intellectual property encompasses property that emerges from all creations of the intellect. One of the most widely used definitions is present in the Convention Establishing the WIPO, containing enumeration of the intellectual property rights. According to this provision:

“ 'intellectual property' shall include the rights relating to: literary, artistic and scientific works, performances of performing artists, phonograms, and broadcasts, inventions in all fields of human endeavor, scientific discoveries, industrial designs, trademarks, service marks, and commercial names and designations, protection against unfair competition, and all other rights resulting from intellectual activity in the industrial, scientific, literary or artistic fields" (Article, paragraph vii, Convention Establishing the World Intellectual Property Organization, signed at Stockholm on July 14, 1967 and as amended on September 28, 1979).

Following the contemporary intellectual property theory, even among legal academics there are notions that intellectual property has become the property right of the XI century (Markovic, 2006). Such characteristics are directly affiliated to the novelty and the uniqueness demanded by the markets, as well as to the innovation and market as emphasized by the companies in the 1990s, i.e. after the beginning of the 'information age'.

Today there is no dilemma on the existence of a strong interdependence between economics and intellectual property. Both lawyers and economists follow the standard division of intellectual property to industrial property on one side and copyrights and related rights on the other side, not neglecting the competition law as a third affiliate component to this concept.

In the area of industrial property, typical law and economics approaches mostly deal with patents, trademarks, designs and geographical indications as a huge segment of the 'intellectual capital' of each enterprise, but also as a powerful tool for development of each national economy.

As far as the patents are concerned, recent academic works focus on several issues of importance of patents: the actual impact of strong patents on innovation, commercialization, and economic growth; institutional factors, ranging from the structure of research organizations to seemingly tangential laws, the translation of patent policy into innovation and research and development (R\&D), etc. (e.g., Hahn, 2003). The main recommendations for future activities in using patents encompass data collection of R\&D output by the government agencies, research on patent policy implementation and policy changes.

From the aspect of trademarks, the relation towards economics is even more obvious. The basic trademark function is to identify certain product or service 
and to assist the customer in making the right choice. Certificate and collective trademarks add another important characteristic: they are proof of a certain quality or standard. The value of the trademark is also a significant intangible asset, having in mind the economic benefits that emerge from its possession (Smith, 1997).

Other segments of industrial property, such as the design (as related to the aesthetical dimension) and the geographical indications (by pointing out origin in a geographical area, which also might refer to certain quality) also play a significant role from economic point of view.

However, the role of copyright and neighboring (related) rights should not be neglected. The internet and the digitalized works have fostered the actualization of copyright, at both international level, through the so called "internet treaties" (WCT and WPPT), and national legislation level. Within these processes, economic effects still remain predominant.

\subsection{Copyright and Neighboring Rights}

From a legal perspective, copyright refers to the protection of all kinds of literary and artistic works that constitute the intellectual property of the author. Despite the differences between the common and civil law approaches, copyright has become equally attractive at both national and international levels.

Simultaneously with the copyright protection, whose main pillar is the Berne Convention, a supplement system for the protection of rights of performers and producers was established in 1961. This is the so called Rome Convention or the International Convention for Protection of Performers, Producers and Broadcasting Organizations. The necessity of regulating these so called neighboring (or related) rights was a result of the acknowledgement of the rights of all factors that "give life" to a certain work, i.e. that make the work available for the public. The protection of databases is also part of the copyright and neighboring rights, getting even more prominence, particularly from the aspect of sui generis protection.

Modern development issues related to management, e-commerce, rights management information and technological measures for protection have become field of interest for the contemporary copyright law, as well.

However, copyright and neighboring rights dimensions go much beyond the legal dimensions. The two opposite premises of copyright are well elaborated by Goldstein (2001), who suggests that the philosophy of copyright is quite utilitarian, since its purpose is to stimulate production of creative goods at lowest possible price. This means that legislators would adopt copyright laws if this is indispensable for stimulation of new works, while the authors will seek protection as this is one of her or his natural rights. Thus, recent academic attempts to apply economic approach to the copyright law are providing strong indication of the interdisciplinary nature of copyright and neighboring rights. 


\subsection{Analyzing Copyright through Economic Lenses}

Copyright grants to writers, composers and other artists a property right in their creation on demonstration that their work is an original expression. This excludes others from copying their work without permission, thus creating intellectual property rights for literary and artistic works, overcoming some of the public goods aspects of information goods by preventing free-riding. Hence, it also encompasses an analysis of the implications for innovation and temporary monopoly or constrained discrimination.

One of the most important economic insights into the intellectual property is the 'public good' aspect. The created work involves relatively high costs of expression: the author's time and efforts plus the costs for editing and publishing. Yet once the copies of created work become available to the market, they are subject to non-rival consumption at a very low cost. In other words, information goods, such as the copyrighted material, have high fixed costs of production and relatively low marginal costs of reproduction and distribution.

Without limiting copying of the original work, the author's expected revenue will be well below the expected cost and he or she will have no incentive for further creation. Therefore, it is widely recognized that a lack of copyright might lead to a lack of incentives for creators and thus to underproduction.

On the other hand, the limited access - often through very high prices or exclusive distribution - for the copyright users and strict enforcement of copyright protection gives a certain degree of temporary market power to the creator. In such case, the characteristic of 'public good' and the positive externalities stemming from the created are suppressed and the society incurs large social costs for the protection of the author's originality and of the private benefits. In this case, the market power encourages authorship by allowing creators and their authorized publishers to capture a return above the marginal costs of expression. Pricing above the marginal cost usually results in fewer copies being purchased than if the books were sold at the lower competitive price. For instance, some persons who value copies above the marginal costs will instead purchase things they value less. As a consequence of this reduced access to the work, copyright produces deadweight loss for the society.

This highlights the important efficiency trade-off between social and private costs that has to be addressed by the copyright laws in order to achieve the delicate balance between the rights of copyright proprietors and the copyright users. Therefore, copyright protection has to be limited in breadth and duration. The breadth of copyright concerns the uses to which copyrighted material can be put without authorization. For instance, a broad copyright forbids any unauthorized use, whereas a narrow copyright permits some unauthorized uses on the basis of fair-use exclusions. For instance, a vague line, frequently litigated, divides fair and unfair use unauthorized copying. The duration of property rights in copyright is also limited as an attempt to minimize the social 
costs of monopoly. The deadweight loss could be minimized if the copyright owner is able to discriminate among consumers on the basis of willingness to pay (Lindsay, 2002).

For illustration purposes, Table 1 offers a brief summary of the main private and external benefits and costs stemming from the copyright protection. The private benefits of the copyright owner consist of the discounted value of future streams of expected revenue from the legally sold copies as well as certain reputational benefits. Since the author could have devoted time and efforts to other projects or copyrightable works, he or she has opportunity costs in terms of the potential revenue from the most valuable forgone alternative. Moreover, the author bears the private costs for editing, publishing, and organizing the book distribution channels. Apart from the private benefits and costs, the copyright material causes costs or benefits to third party stakeholders (external costs and benefits). For instance, the information embodied in the copyright material may exhibit features of public good. Assuming that the copyright offers technological breakthrough, one should expect improved economic efficiency, particularly in those industries which produce goods with large share of intellectual property content, as well as higher efficiency of investment. Yet there are certain external costs for the society, stemming from the restricted access to copyright users as well as costs of administering copyright protection.

TABLE 1: Social (private and external) benefits and costs of copyrighted material

\begin{tabular}{|l|l|}
\hline \multicolumn{1}{|c|}{ Social benefits } & \multicolumn{1}{c|}{ Social costs } \\
\hline Private benefits & Private costs \\
$\begin{array}{c}\text { Present value of future streams of revenue for } \\
\text { the author } \\
\text { Reputational benefits for the author }\end{array}$ & $\begin{array}{c}\text { Estimated author's opportunity costs (time } \\
\text { and effort) } \\
\text { Costs for editing, publishing, advertising and } \\
\text { distribution }\end{array}$ \\
\hline External benefits & External costs \\
\hline $\begin{array}{c}\text { "Public good" content of the information } \\
\text { embodied in the copyrightable work }\end{array}$ & $\begin{array}{c}\text { Losses from limiting access to copyright } \\
\text { users (costs in allocative efficiency of } \\
\text { restricted access) }\end{array}$ \\
$\begin{array}{c}\text { Improved economic efficiency } \\
\text { More efficient levels of investment in } \\
\text { producing resources }\end{array}$ & \\
\hline
\end{tabular}

Source: Authors' summary of the theoretical guidance.

The "excessive" degree of copyright protection is associated with sizeable costs in terms of allocative efficiency, because of the deprived access to a number of potential copyright users and the suppressed 'public good' component. Therefore, not all creative work could be protected by all means. For copyright law to promote economic efficiency and innovation, its principal legal doctrines must, at least approximately, maximize the benefits from creating additional works minus both the losses from limiting access and the costs of administering 
copyright protection. The practice demonstrates that even most sophisticated cost-benefit analysis of the efficiency trade-off could serve only as a rough indicator for designing the breadth and duration of the copyright protection. In this context, the economic analysis of law has developed a number of intangible asset valuation approaches to copyrights, such as the cost, income and market approach.

\section{The Size of the Problem: Piracy Rates}

The collaboration between economics and copyright law is illustrated by the piracy rates among the transition economies. The poor copyright protection in most transition countries indicates that originality and authorship have been ignored for more than twenty years. To illustrate the implications of the weak implementation of copyright and neighbouring rights, we refer to recent studies of global piracy rates in the software area which indicate that Central and Eastern Europe has the highest piracy rate in the world (see Figure 1). While the European Union has an average rate of illegal copying of software of $36 \%$, the study reveals that the Central and Eastern European transition economies illegally obtained $65 \%$ of the installed software in 2006 .

Figure 1: Piracy RATES BY WorLd REGIONS IN 2007 AND 2011 (IN PERCENT)

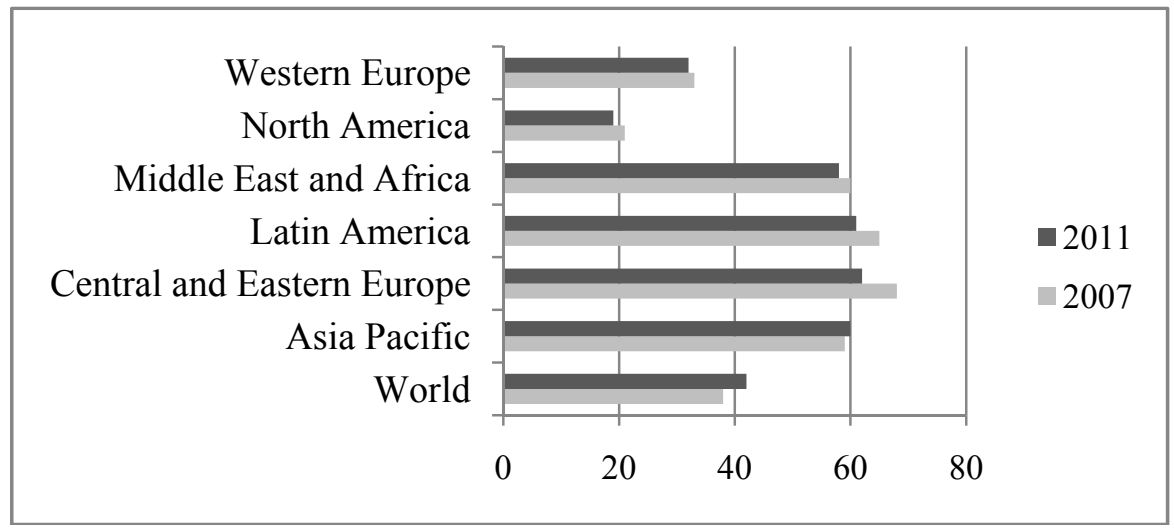

Source: The Ninth Annual BSA and IDC Global Software Piracy Study, Business Software Alliance, May 2012.

Descriptive statistical analysis of the copyright protection in the software area reveals that within Central and Eastern Europe, Georgia has the highest piracy rate (91\%), whereas the Slovak Republic demonstrates the strongest commitment to combat piracy (40\%). We confront data on Gross Domestic Product (GDP) per capita (in purchasing power parity terms) from the International Finance Statistics published by the International Monetary Fund, with estimated piracy rates, published by the Business Software Alliance (BSA) to check for possible empirical regularities (Figure 2). 
FIGURE 2: PIRACY RATES AND GDP PER CAPITA (IN PURCHASING POWER PARITY TERMS, IN US\$) IN 24 EUROPEAN

TRANSITION ECONOMIES IN 2011

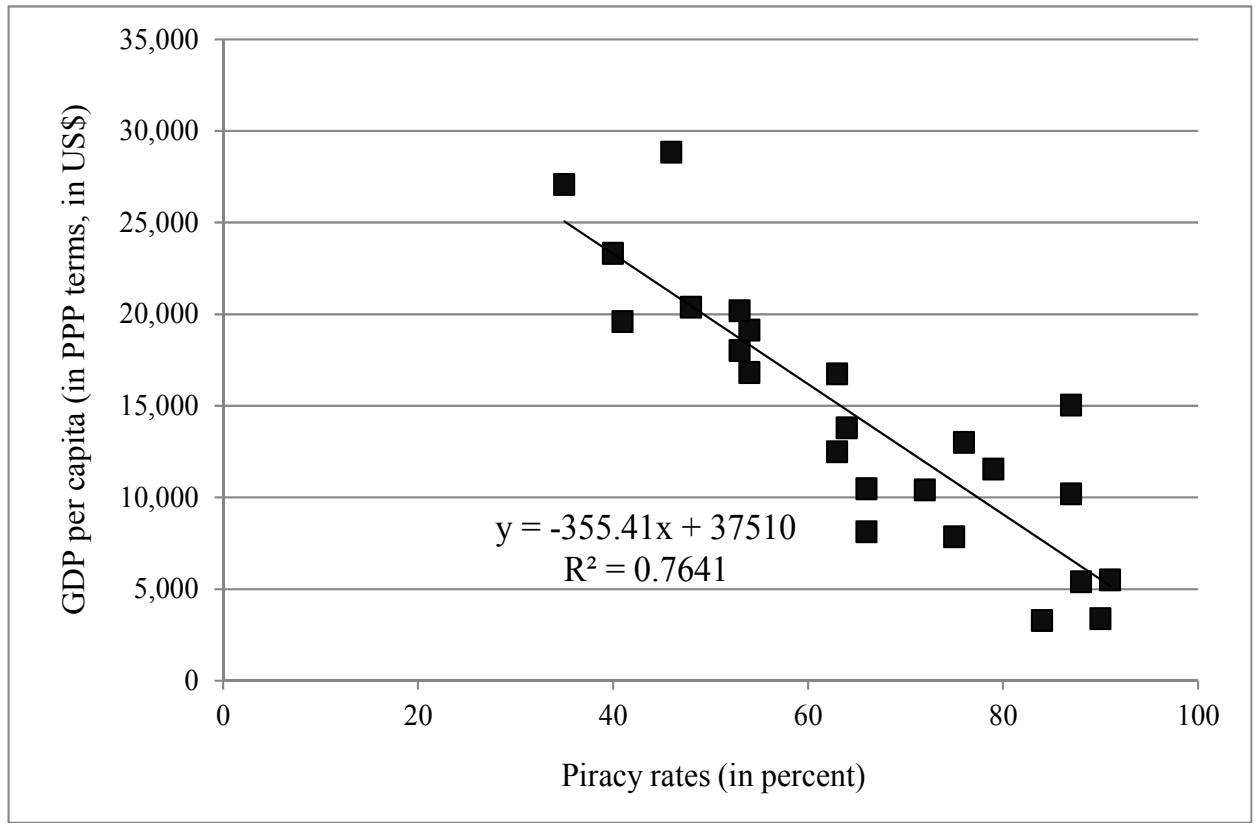

Source: International Finance Statistics (IMF) and the Fourth Annual BSA and IDC Global Software Piracy Study, Business Software Alliance, 2012.

The Pearson product-moment correlation coefficient between piracy rates and income per capita is rather high $(-0.87)$ and it is statistically significant at the $1 \%$ level, indicating that higher GDP per capita is associated with lower piracy rates. It also implies that high piracy rates occur when the income gap is high among the potential software users and the enforcement policy against the pirates is less strict. However, correlation does not necessarily imply causation, which is an issue that is examined in the next section.

\section{The Bidirectional Causality between Copyright Protection and Economic Development}

A large body of existing empirical literature suggests that higher economic growth promotes improved copyright protection. Indeed, higher per capita income reduces the incentives for unauthorized exploitation of the created work, whereas upgraded institutional capacity simultaneously increases the probability of copyright prosecution and firm's incentives to innovate. Moreover, increasing economic globalization and technological development require continuous adaptation of the intellectual property rights instruments, because: (i) the share of goods and services with intellectual property content in the international trade 
is expanding, and (ii) the structural competitiveness depends on innovations and imitation of foreign technologies.

More important is to recognize that investment in new research and development and human capital formation is one of the key driving forces behind economic growth. For instance, the endogenous growth theory attaches crucial importance to the production of new technologies and human capital formation. In large part, they depend on 'originality' and 'innovation', which are key elements in defining a work that qualifies for copyright protection. Again, this brings us to the already noted central dilemma related to the optimal level of copyright protection, which must trade-off the benefits in terms of improved efficiency of creating incentives for creation against the costs in terms of restricted access.

Figure 3: Strength of InTELlectual Property Protection AND GDP PER CAPITA (IN PURCHASING POWER PARITY TERMS, IN US\$) IN 24 EUROPEAN TRANSITION ECONOMIES IN 2011

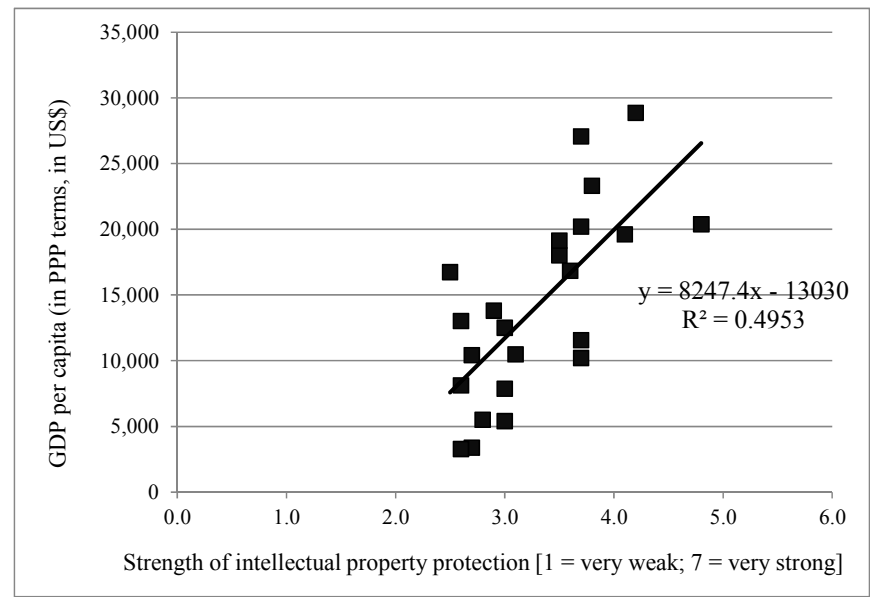

Source: International Finance Statistics (The International Monetary Fund), 2012; The Global Competitiveness Report 2011-12, World Economic Forum.

\section{Concluding Remarks}

In recent decades, economic analysis of law has gained prominence not only within the academic community, but also in the legal practice. Copyright has become a fast growing area of a successful cooperation between law and economics. This calls for advanced microeconomic analytical skills and a high level of legal understanding of intellectual property rights. Such interdisciplinary perspective is indeed necessary to deal with the central dilemma between access to copyright users and incentives to authors, by raising important issues under the umbrella of the microeconomics of copyright and macroeconomic consequences of piracy. 
The understanding of economics of copyright undoubtedly plays a significant role for copyright and intellectual property in general. One can assume that this will indeed be recognized in the teaching of intellectual property throughout the world. Furthermore, intellectual property rights enforcement is expected to be mainly determined by economic goals. Our current digital era, in particular, thus renders economics of copyright, together with economics of industrial property and the competition law crucial in the successful management of intellectual property rights.

\section{References}

Conley, John And Christopher S. Yoo (2009), "Nonrivalry and Price Discrimination in Copyright Economics", University of Pennsylvania Law Review, June 2009, Vol. 157, No. 6, pp. 1801-1830.

Goldstein, Paul (2001), International Copyright: Principles, Law and Practice, Oxford: Oxford University Press.

Hahn, R. W. (2003), The Economics of Patent Protection: Policy Implications From The Literature, AEI-Brookings Joint Center for Regulatory Studies, Washington, DC.

HSIUNG, BINGYUAN (2006), "Economic Analysis of Law: An Inquiry of Its Underlying Logic," Erasmus Law and Economics Review, Vol. 2, No. 1, March 2006, pp. 1-33.

IDRIS, KAMIL (2001), Highlights: Study on the Economic Importance of Industries and Activities protected by Copyright and Related Rights in the MERCOSUR Countries and Chile, WIPO Publication No. 889(E), World Intellectual Property Organization, Genève.

LindSAY, DAVID (2002), The Law and Economics of Copyright, Contract and Mass Market Licenses, Research Paper, Centre for Copyright Studies, Strawberry Hills, Australia.

Marković, Svetozar (2007), "Intellectual Property Rights, Culture of Dematerialized Property, Strategic Use of Intellectual Property Rights for Economic and Social Development," WIPO and SOIP Regional Seminar, Ohrid, May 2007.

Romer, PaUl (1990), Endogenous Technological Change, The Journal of Political Economy, Vol. 98, No. 5, pp. S71-S102.

SMith, Gordon V. (1997), Trademark Valuation, New York: John Wiley and Sons Inc.

Smith, Gordon V. AND Russel L. PARR (2000), Valuation of Intellectual Property and Intangible Assets, Third edition, New York: John Wiley \& Sons, Inc. 
Smith, Pamela J.; Da'ar, Omar B.; Monroe, Kevin H.; Nunez, Fabricio X.; Tuttle, Charlotte J. (2009), "How Do Copyrights Affect Economic Development and International Trade?", Journal of World Intellectual Property, May 2009, Vol. 12, No. 3, pp. 198-218.

Towse, Ruth (2008), "Copyright and Artists: A View from Cultural Economics", In: Recent Trends in the Economics of Copyright, pp. 23654, Elgar Reference Collection. International Library of Critical Writings in Economics, vol. 224, Cheltenham, U.K. and Northampton, Mass.: Elgar.

WALter, PARK (2010), The Copyright Dilemma: Copyright Systems, Innovation and Economic Development, The Journal of International Affairs, Vol. 64, No. 1, pp. 53-68.

WIPO COPYRIGHT TREATY (WCT).

(WPPT) WIPO PERFORMANCE AND PROGRAMME TREATY. 